\title{
Modal Particles in Dutch as a Second Language. Evidence from a Perception Experiment ${ }^{*}$
}

\author{
Johanneke Caspers/Ton van der Wouden (Leiden)
}

\begin{abstract}
The perception of modal particles in Dutch was studied, contrasting native and speakers of Dutch as a second language (DSL). According to expectations, non-native subjects turned out to have more significant problems with selecting the best fitting stimulus in the contexts designed to evoke a modal use of the target word. Contrary to expectation, however, the nonnative subjects had problems with non-modal contexts as well. Work on spontaneous speech elicited from DSL-speakers with Spanish as L1 revealed an unexpected but clear hierarchy in the acquisition of modal particles. The results are taken as an indication that Dutch particles, as well as their interaction with prosody, merit more attention in didactic materials aimed at DSL-speakers.
\end{abstract}

\section{$1 \quad$ Introduction}

This study examines the perception of modal particles in Dutch, contrasting native and nonnative speakers. The term "modal particle" will be used as a cover term for a group of highfrequent words found in real-life discourse in languages such as German, Dutch and classical Greek, used to express meaning nuances in various areas like modality, evidentiality and aspect (cf. e. g. Weydt (1977) where comparable elements are called "Modalpartikeln" or "Abtönungspartikeln"; Schiffrin (1987) where we find the term "discourse markers", and Foolen (1996) who speaks of "pragmatic particles"). Whether or not modal particles constitute a proper subset of the class of adverbs (or of any other syntactic or semantic class of lexical items) is a question beyond the scope of this paper (cf. e. g. Henschel/Weydt 1989).

Given that languages differ considerably both in the number of particles they have and in the ways they are deployed, it has been hypothesized that they constitute a problem for nonnative speakers (cf. Weydt 1981; Foolen 1986). Mastering Dutch particles is furthermore complicated by the fact that the grammatical and semantic properties of Dutch particles are treated incompletely (at best) in grammars and dictionaries (cf. Wouden/Caspers, 2010) and in learning materials (cf. Foolen 2010). Modal particles may be particularly difficult for second language learners to master, not only because of strong mismatches between languages as regards their usage of such lexical elements, but also because this class of words shows an intricate association between word meaning and prosodic parameters (cf. Foolen 1986; Cheon-Kostrzewa 1996; Wenzel 2002; Möllering 2004). In the large majority of cases, modal particles in Dutch do not carry a pitch accent, i. e., they are not highlighted by a conspicuous melodic movement (cf. König 1991; Vismans 1994).

Very often, Dutch modal particles have an accented counterpart in one or more other word classes (cf. e.g. Abraham 1984). For our experiment, we have chosen particles with an adverbial counterpart. At times, we will be somewhat sloppy in our terminology and refer to

\footnotetext{
* Nanda Bakker, Erna van Balen, Xuelian Chu, Sarah von Galambos, Aafke Groot, Marleen Kunneman, Oksana Melnychuk, Rogier van Nierop, Nadine Otting and Claasje Reijers are thanked for their contribution to the research seminar that was conducted in 2007 under supervision of the authors. An earlier version of this paper was published as Caspers/Van der Wouden (2008).
} 
the accented counterpart as "(normal) adverb" or "adverbial interpretation". For example: (1a) below exemplifies a use of the modal particle zeker, (1b) shows the adverb zeker: ${ }^{1}$

(1a) Dat doet zeker PIJN

That does [part] PAIN

'I presume that HURTS'

(1b) Dat doet ZEKER pijn

That does CERTAINLY pain

'That certainly DOES hurt'

In example (1a) there is a pitch accent on the noun pijn (indicated by the capitals), while the word zeker remains unaccented. As a result, zeker functions as a modal particle, giving the whole utterance an uncertain, testing flavor - it almost functions as a (yes-no) question. In example (1b) pijn is unaccented and the sentence accent in this case is located on zeker, leading to an adverbial interpretation of the word (i. e. 'certainly').

Dutch intonation has to do with information structure and focus (cf. Keijsper 1985; Baart 1987). In light of the kind of things modal particles contribute to the semantics and pragmatics of utterances, it is hardly surprising that these lexical elements cannot be focused, which helps us understand why they cannot be accented. On the other hand, modal particles are sensitive to information structure: At least since Krivonosov (1963) we know that they tend to mark the borderline between theme and rheme, i. e., between old and new information. In Dutch, both phrases carrying old information and those that express new information can be, and often are, prosodically marked, e.g. by means of a pitch accent. The preferred position of modal particles is then by definition one between two accented phrases, and therefore unaccented (cf. Vismans 1994).

With respect to second language acquisition, prosody has been virtually ignored for a long time (Chun 2002). Recently, however, it has been established that prosodic factors such as stress position and pitch accent placement are crucial for judgements of non-nativeness and comprehensibility of L2 speech (Anderson-Hsieh et al. 1992; Munro/Derwing 1995, 1998; Trofimovich/Baker 2006).

The results and conclusions of the few studies on transfer of prosodic characteristics (from L1 to L2) that have been carried out do not all point into the same direction. Some experimental studies involving Dutch do report transfer (cf. Mennen 2004; Roosman 2006; Rasier 2006), others do not (cf. Caspers/Santen 2006). Mennen (2004) found evidence for transfer of the phonetic implementation of pitch rises from L1 Dutch to L2 Greek. Roosman (2006) reports L1 influence on the realisation of word stress in L2 Dutch. Rasier (2006) concludes that the location of sentence accent is transferred from L1 French to L2 Dutch. On the other hand, Caspers/Santen (2006) did not find evidence for influence of L1 on the location of word stress in spoken L2 Dutch.

To our knowledge, no experimental work has been done on the perception by second language learners of different accent distributions in Dutch. On the basis of the available literature it is to be expected that - unaccented or deaccented - modal particles are difficult for L2 learners of Dutch to interpret, and the experiment we discuss in the current paper was explicitly set up to establish whether this problem actually exists.

\section{Approach}

We devised a perception experiment in which subjects were presented with a context sentence and two stimulus sentences, differing only in the presence versus absence of a pitch accent on the target word. The context sentences were constructed in such a way that they would fit either an adverbial (accented) or modal (unaccented) reading of the stimulus sentence.

\footnotetext{
${ }^{1}$ Example (1a) does not have a suitable word-for-word translation, because modal particles are virtually nonexistent in English (and in many other languages). It should be mentioned that one might meet adjectival usages of zeker as well, as in Een onderneming opstarten is altijd een zeker risico 'starting a business always involves a certain risk', and zeker might even be a form of the verb zekeren 'secure'.
} 
We selected the following modal particles for our investigation: wel ('rather', 'quite'), zeker ('probably') and toch (untranslatable, indicates that confirmation is expected). The words chosen share the property that their interpretation as adverb or modal particle depends on the presence versus absence of a pitch accent. Furthermore, they have been investigated earlier (cf. Schermer-Vermeer 1984; Vismans 1994; Abraham 1984, Wouden 1999; Hogeweg 2005, 2009), which means that at least some of their properties are known.

We hypothesized that speakers of Duch as a second language (DSL-speakers) would have problems with the distinction between modal and adverbial use of words like zeker. We expected the control group to select stimuli with accented target words in non-modal contexts in the majority of cases, and stimuli with unaccented target words in modal contexts. For the non-native subjects, the largest problems were expected for the modal contexts. We thought it possible that the non-modal contexts, i. e. the stimuli containing accented target words might be responded to correctly, if only because accented lexical items are more salient than unaccented ones.

\section{$3 \quad$ Method}

\subsection{Stimulus Materials}

For each of the three target words five different stimulus sentences were created. The sentences were ambiguous as to the interpretation of the target as a modal particle or a regular adverb. They were read aloud by a trained speaker, who realized pitch accents at indicated positions, resulting in either a modal or a non-modal version of the sentence. In addition, the stimulus sentences were preceded by context sentences that were intended to lead to either a modal or a non-modal interpretation of the target word in question. Below examples are given of context and stimulus sentences; for the stimulus sentences the intonation contour is indicated à la Bolinger (1989):

Context A:

Je hoeft geen stoel voor Sander klaar te zetten

'You don't have to put a chair out for Sander'

Stimulus a):

Hij komt ze- ker niet

He comes cer- tainly not

'He certainly won't come'

Stimulus b):

komt

Hij zeker niet

$\mathrm{He}$ comes certainly not

'I presume he won't come'

The pitch accent on zeker in stimulus a) triggers an adverbial interpretation (i. e. 'certainly') and therefore the sentence is an appropriate continuation in the given context. In stimulus b), zeker remains unaccented and the pitch accent in this case falls on the verb komt. As a result, zeker can only function as a modal particle, indicating a form of uncertainty, which does not fit context A very well.

The alternative context for these stimulus sentences - fitting a modal use of zeker, i.e. stimulus b) - is:

Context B:

De stoel van Sander is nog leeg

'Sanders chair is still empty'

For the complete set of stimulus materials see the appendix.

After verification and segmentation, using PRAAT (Boersma/Weenink 2006), the digital recordings were placed in a single audio file. Every context sentence occurred once, followed 
by both versions of the corresponding stimulus sentence (the relative order of the accented and unaccented versions was varied quasi-randomly). Context and stimulus sentences were presented twice in succession, in a fixed random order, with fixed pauses, and separated by beeps.

\subsection{Subjects}

A control group of 25 speakers of Dutch as a first language (DFL-speakers) participated in the experiment. They were between 20 and 27 years old, and 11 of them were male. The 17 DSLspeakers (late learners of Dutch) were first year students at the department of Dutch Studies at Leiden University. They had all followed exactly the same educational programme from September 2006 to May 2007, containing a large amount of language instruction. Their level was between A2 and B1, according to the Common European Framework of Reference (cf. Council of Europe 2001), ${ }^{2}$ ages varied between 20 and 41, and 5 were male. Eight DSLspeakers had Chinese as their first language (7 Mandarin, 1 Cantonese), the remainder of the group spoke an Indo-European language. No hearing problems were reported and all subjects participated on a voluntary basis.

\subsection{Procedure}

The group of native subjects was tested in one session, the non-native subjects, for practical reasons, in two other ones. The sessions all started with the distribution of answer booklets. On the first page the subjects had to fill in a short questionaire (year and place of birth, mother tongue, L3, etc.). Then they had time to read the instructions and to ask questions. Subjects were instructed to listen to context and stimulus sentences and mark on the answer sheets which of the two versions of the stimulus sentence they thought fitted the presented context best. A practise item was then played, after which questions could again be asked. Next, the experiment was run, without any further pauses. Both context and stimulus sentences were printed in the answer booklet, without an indication of the pitch accent position, differing the two stimulus sentences with (a) and (b). Subjects had to circle either the (a) or the (b) version, depending on which version they thought best suited the presented context.

\section{$4 \quad$ Results}

Table 1 contains the number of "correct" (i. e. unaccented targets in modal contexts and accented targets in non-modal contexts) and "incorrect" responses for the native and nonnative speakers. For the group of non-native subjects, one case was missing.

\begin{tabular}{lccc}
\hline & & responses & \\
subject group & correct & incorrect & total \\
\hline native & $676(90 \%)$ & $74(10 \%)$ & 750 \\
non-native & $288(57 \%)$ & $221(43 \%)$ & 509 \\
\hline total & $964(77 \%)$ & $295(23 \%)$ & 1259 \\
\hline
\end{tabular}

Table 1: Absolute (and relative) frequency of correct and incorrect responses, for native versus non-native speakers of Dutch

The data show that the DFL-speakers have a mean score of $90 \%$ correct responses, while the DSL-speakers have a mean of $57 \%$ correct responses (Pearson $\chi^{2}=190.256$, $\mathrm{df}=1$, $\mathrm{p}<.001)$.

In figure 1 the data for both the native and non-native speakers are broken down further by context type and target word.

\footnotetext{
2 It was brought to our attention that this level might be too low for the rather complex task investigated. The results given below, however, at least partially refute this critique. The experiment might of course be repeated with more advanced students, and probably should.
} 

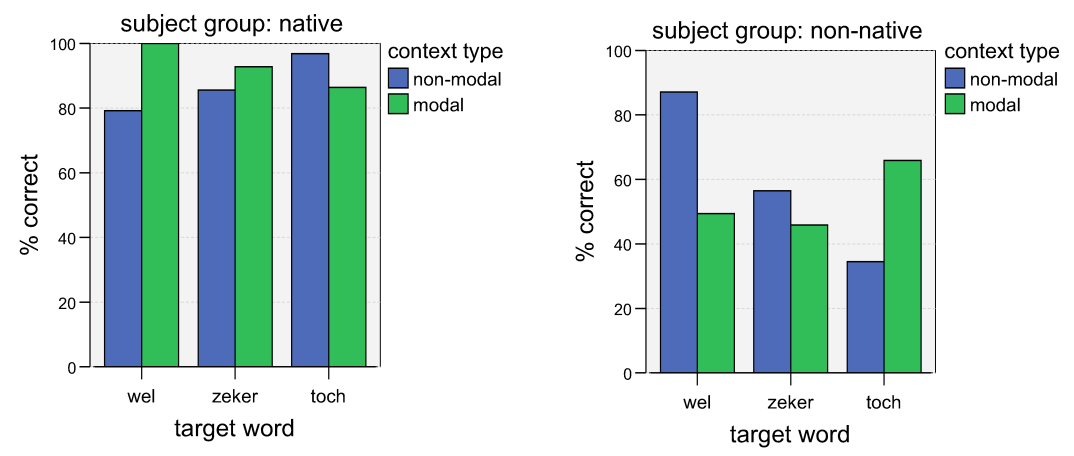

Figure 1: Percentage of correct responses per target word, broken down by context type, for native versus non-native speakers.

An analysis of variance on percentage correct reveals a large effect of nativeness $\left(\mathrm{F}_{(1,1257)}=245.495, \mathrm{p}<.001\right)$, and a small main effect of target word $\left(\mathrm{F}_{(2,1256)}=6.819\right.$, $\mathrm{p}<.005)$. There is no main effect of context type $\left(\mathrm{F}_{(1,1257)}<1\right.$, insignificant $)$, which means that overall there is no significant difference in the number of correct responses to the modal and non-modal contexts. However, there are significant two-way interactions between nativeness and target word $\left(\mathrm{F}_{(2,1251)}=8.342, \mathrm{p}<.001\right)$, between nativeness and context type $\left(\mathrm{F}_{(1,1253)}=7.182, \mathrm{p}<.001\right)$ and between target word and context type $\left(\mathrm{F}_{(2,1251)}=6.650\right.$, $\mathrm{p}<.005)$. Finally, there is a strong three-way interaction $\left(\mathrm{F}_{(2,1247)}=46.005, \mathrm{p}<.001\right)$.

It is clear that wel is responded to differently by the native speakers in the modal and nonmodal conditions: in a context designed to trigger a preference for accented wel, the subjects indeed selected accented wel in $79 \%$ of the cases, but the responses rise to a full $100 \%$ preference for unaccented wel in the modal context condition. This means that native speakers feel very strongly about unaccented wel in these contexts: Apparently, the stimulus with the accented version is completely unacceptable. The reverse is not true: in non-modal contexts the preference for the accented version of wel is not absolute, in a fifth of the cases subjects select the unaccented version. The difference between modal and non-modal contexts is significant for wel (Pearson $\chi^{2}=29.018, \mathrm{df}=1, \mathrm{p}<.001$ ). The same is true for toch, albeit that the difference is much smaller and reversed (Pearson $\chi^{2}=8.786, \mathrm{df}=1, \mathrm{p}<.005$ ). Closer inspection of the data reveals that this effect is caused by one ambiguous context sentence (context $1 \mathrm{~b}$ for zeker allows a modal as well as a non-modal interpretation). For zeker the effect of context type is not significant (Pearson $\chi^{2}=3.363, \mathrm{df}=1$, insignificant).

The non-native speakers have a higher percentage of correct responses for wel in non-modal contexts than the native subjects (87\% vs. $79 \%)$, but a much lower score in the modal condition (49\% vs. $100 \%)$. The responses for the other two particles show mirrored effects for both groups of speakers as well, which explains the strong three-way interaction reported above.

Wel in a non-modal context is the only condition the DSL-group seems to be really comfortable with $(87 \%$ correct); the difference between modal and non-modal contexts is significant for wel (Pearson $\chi^{2}=27.791, \mathrm{df}=1, \mathrm{p}<.001$ ). For zeker the responses do not differ in the two types of context (Pearson $\chi^{2}=48.839$, $\mathrm{df}=1$, insignificant); the scores appear to be random here (on average $51 \%$ correct), indicating that the stimuli in both context types are generally hard for the subjects to interpret. Finally, there is a significant difference in the number of correct responses to the target word toch per context type (Pearson $\chi^{2}=16.619, \mathrm{df}=1, \mathrm{p}<.001$ ); in de modal contexts $66 \%$ of the responses is correct, while in the non-modal contexts only $35 \%$ of the responses is correct. It seems that there is a general preference for unaccented toch, irrespective of context type. We do not have an full explanation for this finding, but it could be the case that unaccented toch is much more frequent in spoken Dutch than accented toch.

\section{$5 \quad$ Discussion and Conclusion}

It became clear that non-native subjects have problems with selecting the best fitting stimulus in the contexts designed to evoke a modal use of the target word, as we expected. However, in the non-modal contexts they experienced difficulty as well, except with the stimuli containing 
the target word wel. It appears that the DSL-speakers find zeker and toch more difficult than wel. This could be explained by the fact that accented wel is in direct opposition with the negation niet (not), which makes it highly contrastive and rather hard to miss for DSLlearners. ${ }^{3}$

Recent work on spontaneous speech elicited from DSL-speakers with Spanish as L1 revealed an unexpected but clear hierarchy in the acquisition of modal particles (cf. Balen et al. , 2010). It turned out that the higher the proficiency level of the subject, the more modal particles were used, and a ranking in difficulty was possible for the different particles. When a Spanish DSL-speaker uses modal particles, maar is the first one to appear, followed by wel; toch is tenth in line, and zeker is not used at all by the investigated group of speakers. Furthermore, the non-modal use of the target words shows a parallel pattern: wel is more frequent than toch, and zeker is completely absent from the DSL-data. It seems that wel is acquired much earlier than toch, and zeker clearly is the hardest.

We are inclined to interpret the results of our experiment as an indication that Dutch particles, as well as their interaction with prosody, merit more attention in didactic materials aimed at DSL-speakers. It seems reasonable to reserve some (more) time for the phenomenon of accentuation (its nature and function), and to try to make the students sensitive to the fact that the meaning of Dutch words can depend on whether or not they carry accent. Moreover, examples of Dutch modal particles and their accent-carrying adverbial counterparts should be offered (in context), in order to create a certain consciousness for modal particles and their contribution to the meaning and usage possibilities of utterances. The lack of descriptive work, however, will not make this a trivial task.

\section{References}

Abraham, Werner (1984): "De betekenis en de functie van het nederlandse wel - een vergelijking met het Duits". In Auwera, Johan van der/Vandeweghe, Willy (eds.): Studies over Nederlandse partikels. Antwerpen, University of Antwerpen: 19-46.

Anderson-Hsieh, Janet/Johnson, Ruth/Koehler, Kenneth (1992): "The relationship between native speaker judgments of nonnative pronunciation and deviance in segmentals, prosody, and syllable structure". Language Learning 42: 529-555.

Baart, Joan (1987): Focus, Syntax, and Accent Placement. Towards a system for the derivation of pich accent patterns in Dutch as spoken by humans and machines. $\mathrm{PhD}$ thesis, Leiden University.

Balen, Erna van/Caspers, Johanneke/Wouden, Ton van der (2010): "Modale partikels in het Nederlands als tweede taal: aanwijzingen voor een vaste verwervingsvolgorde". Internationale Neerlandistiek 48: 31-40.

Boersma, Paul/Weenink, David (2006): "Praat: Doing phonetics by computer". Version 4.4.24. http://www.praat.org.

Bolinger, Dwight (1989): Intonation and its uses: Melody and grammar in discourse. Stanford: Stanford University Press.

Caspers, Johanneke/Santen, Ariane van (2006): "Nederlands uit Franse en Chinese mond, Invloed van T1 op de plaatsing van klemtoon in Nederlands als tweede taal?". Nederlandse Taalkunde 11: 289-318.

Caspers, Johanneke/Wouden, Ton van der (2008): "The perception of modal particles in Dutch as a second language". Toegepaste Taalwetenschap in Artikelen 80: 9-18.

Cheon-Kostrzewa, Bok Ja (1996): Der Erwerb der Deutschen Modalpartikeln. PhD Thesis, FU Berlin.

Chun, Dorothy (2002): Discourse intonation in L2, From theory and research to practice. Amsterdam: Benjamins.

Council of Europe (2001): Common European framework of reference for languages, Learning, teaching, assessment. Cambridge: Cambridge University Press.

Elffers, Els (1997): "De onaccentueerbaarheid van modale partikels". In: Elffers-van Ketel, Els/van der Horst, Joop M./Klooster, Willem G. (eds.): Grammaticaal Spektakel. Amsterdam, Vakgroep Nederlandse Taalkunde: 59-70.

Foolen, Ad (1986): "'Typical Dutch noises with no particular meaning': Modale partikels als leerprobleem in het onderwijs Nederlands als vreemde taal". In: Verslag van het negende

\footnotetext{
3 Werner Abraham suggests that the English cognate well is another potential factor (personal communication).
} 
colloquium van docenten in de Neerlandistiek aan buitenlandse universiteiten. 'sGravenhage, IVN: 39-57.

Foolen, Ad (1996): "Pragmatic Particles". In: Verschueren, Jef et al (eds.): Handbook of Pragmatics 1996. Amsterdam, Benjamins: 1-24.

Foolen, Ad (2010): "Partikels volgens de schijf van vijf". Internationale Neerlandistiek 48: 41-51.

Henschel, Elke/Weydt, Harald (1989): "Wortartenprobleme bei Partikeln". In: Weydt, Harald (ed.): Sprechen mit Partikeln. Berlin/New York, de Gruyter: 3-18.

Hogeweg, Lotte (2005): Well, about wel! On the diversity and unity of the Dutch particle wel. MA thesis Faculty of Arts, Universiteit Utrecht.

Hogeweg, Lotte (2009): Word in Process. On the interpretation, acquisition and production of words. PhD thesis, Radboud University Nijmegen.

Keijsper, Cornelia E. (1985): Information structure. With examples from Russian, English and Dutch. PhD thesis, University of Amsterdam.

Krivonosov, Alexej (1963/1977): Die modalen Partikeln in der deutschen Gegenwartssprache. PhD thesis, Humboldt Universität Berlin. Reprinted in Göppingen by Kümmerle.

Mennen, Ineke (2004): "Bi-directional interference in the intonation of Dutch speakers of Greek". Journal of Phonetics 32: 543-563.

Möllering, Martina (2004): The acquisition of German modal particles. A corpus-based approach. Bern: Lang.

Munro, Murray/Derwing, Tracey M. (1995): "Foreign accent, comprehensibility, and intelligibility in the speech of second language learners". Language Learning 45: 73-97.

Munro, Murray/Derwing, Tracey M. (1998): "The effects of speaking rate on listener evaluations of native and foreign-accented speech". Language Learning 48: 159-182.

Rasier, Laurent (2006): Prosodie en vreemdetaalverwerving. Accentdistributie in het Frans en het Nederlands als vreemde taal. $\mathrm{PhD}$ thesis, University of Louvain.

Roosman, Lilie (2006): Phonetic experiments on the word and sentence prosody of Betawi Malay and Toba Batak. PhD thesis, Universiteit Leiden.

Schermer-Vermeer, Ina (1984): "De betekenis van het woord TOCH in samenhang met de rol van intonatie". Forum der Letteren 25: 208-219.

Schiffrin, Deborah (1987): Discourse markers. Cambridge: Cambridge University Press.

Trofimovitch, Pavel/Baker, Wendy (2006): "Learning second language suprasegmentals: Effect of L2 experience on prosody and fluency characteristics of L2 speech". Studies in Second Language Acquisition 28: 1-30.

Vismans, Roel (1994): Modal particles in Dutch directives: A study in functional grammar. $\mathrm{PhD}$ thesis, Vrije Universiteit Amsterdam.

Wenzel, Veronika (2002): Relationelle Strategien in der Fremdsprache. Pragmatische und interkulturelle Aspekte der niederländischen Lernersprache von Deutschen. $\mathrm{PhD}$ thesis, Universität Münster.

Weydt, Harald (ed.) (1977): Aspekte der Moldalpartikeln. Sudien zur deutschen Abtönung. Tübingen: Niemeyer.

Weydt, Harald (ed.) (1981): Partikeln und Deutschunterricht. Heidelberg: Groos.

Wouden, Ton van der (1999): "Over zeker zeker? Zeker!". TABU 30: 63-89.

Wouden, Ton van der/Caspers, Johanneke (2010): "Nederlandse partikelbeschrijving in internationaal perspectief: waar zijn we eigenlijk en waar moet het toch naar toe?" Internationale Neerlandistiek 48: 52-62.

\section{Appendix: Stimulus Materials}

wel

Context 1a: Het feestje was zeker niet leuk? ('I suppose the party wasn't fun?')

Context 1b: Hoe was het feestje? ('What was the party like?')

Stimulus 1a: Het feestje was WEL leuk. ('The party WAS fun')

Stimulus 1b: Het feestje was wel LEUK. ('The party was oKAY')

Context 2a: Was het nieuwe meisje niet aardig? ('Wasn't the new girl nice?')

Context 2b: Hoe is het nieuwe meisje? ('What is the new girl like?') 
Stimulus 2a: Dat nieuwe meisje is WEL aardig. ('That new girl IS nice')

Stimulus 2b: Dat nieuwe meisje is wel AARdig. ('That new girl is oKAY')

Context 3a: Was de komiek niet grappig? ('Wasn't the comedian funny?')

Context 3b: Hoe was de komiek? ('What was the comedian like?')

Stimulus 3a: De komiek was WEL grappig. ('The comedian WAS funny')

Stimulus 3b: De komiek was wel GRAPpig. ('The comedian was oKAY')

Context 4a: Was de voorstelling niet goed? ('Wasn't the performance good?')

Context 4b: Hoe was de voorstelling? ('What was the performance like?')

Stimulus 4a: De voorstelling was WEL goed. ('The performance WAS good')

Stimulus 4b: De voorstelling was wel GOED. ('The performance was oKAY')

Context 5a: Was het geen mooi weer? ('Wasn't the weather nice?')

Context 5b: Hoe was het weer? ('What was the weather like?')

Stimulus5a: Het was WEL mooi weer. ('The weather WAS nice')

Stimulus5b: Het was wel mooi WEER. ('The weather was oKAY')

Zeker

Context 1a: Ik neem de auto. ('I'm taking the car')

Context 1b: Ik zie dat je je regenbroek aanhebt. ('I see you are wearing your rainproof trousers')

Stimulus 1a: Dus jij gaat ZEker op de FIETS. ('So you are DEfinitely going by BIKE')

Stimulus 1b: Dus jij gaat zeker op de FIETS. ('So I presume you are going by BIKE')

Context 2a: Ik weet niet of mijn tante in Papoea heeft gewoond. ('I don't know whether my aunt lived in Papua')

Context 2b: Wat weet je tante veel over Papoea. ('Say, your aunt does know a lot about Papua')

Stimulus 2a: Ze is er ZEker geWEEST. ('She has CERtainly BEEN there')

Stimulus 2b: Ze is er zeker geWEEST. ('I suppose she has BEEN there')

Context 3a: Ik heb zelf nog niks ingepakt. ('I have not packed anything yet')

Context 3b: Ik zie dat er nog niks is ingepakt. ('I see that nothing has been packed yet')

Stimulus 3a: We kunnen vanDAAG dus ZEker niet verTREKken. ('We CERtainly cannot

LEAve toDAY')

Stimulus 3b: We kunnen vanDAAG dus zeker niet verTREKken. ('I presume we cannot LEAve toDAY')

Context4a: Je hoeft geen stoel voor Sander klaar te zetten. ('You don't have to put a chair out for Sander')

Context4b: De stoel van Sander is nog leeg. ('Sanders chair is still empty')

Stimulus4a: Hij komt ZEker niet. ('He CERtainly won't come')

Stimulus4b: Hij KOMT zeker niet. ('I presume he won't COME')

Context 5a: Ja, ik heb in m'n vinger gesneden. ('Yes, I have cut my finger')

Context 5b: Heb je in je vinger gesneden? ('Have you cut your finger?')

Stimulus 5a: Dat doet ZEker pijn. ('That DOES hurt')

Stimulus 5b: Dat doet zeker PIJN. ('I presume that HURTS')

toch

Context 1a: Je mag het stuk taart van Jaap opeten. ('You can eat Jaaps piece of cake')

Context 1b: Waarom staat Jaap op de namenlijst? ('Why is Jaap on the list of names?')

Stimulus 1a: Hij komt TOCH niet. ('He CERtainly won't come')

Stimulus 1b: Hij KOMT toch niet. ('He won't COME, will he?')

Context 2a: Emma wil haar fiets verkopen. ('Emma wants to sell her bike') 
Context 2b: Hoe kan Emma's fiets nou gestolen zijn? ('How can Emma's bike been stolen?') Stimulus 2a: Zij fietst TOCH nooit. ('She never cycles ANYhow')

Stimulus 2b: Zij FIETST toch nooit. ('She never CYcles, does she?')

Context 3a: Er brandt licht bij de buren. ('The light of the neighbours is on')

Context 3b: Waarom pakken de buren de telefoon niet op? ('Why don't the neighbours pick up the phone?')

Stimulus 3a: Ze zijn TOCH thuis. ('They ARE home, after all')

Stimulus 3b: Ze zijn toch THUIS. ('They are HOME, aren't they?')

Context 4a: Jan heeft zich niet goed voorbereid op het tentamen. ('Jan has not been preparing himself for the exam very well')

Context 4b: Waarom ziet Jan er zo somber uit? ('Why does Jan look so gloomy?')

Stimulus 4a: Hij is TOCH geslaagd. ('He passed ANYhow')

Stimulus 4b: Hij is toch geSLAAGD. ('He PASSed, didn't he?')

Context 5a: Laat dat ding maar vallen. ('You can drop that thing')

Context 5b: Kijk uit met dat glas. ('Watch out with that glass')

Stimulus 5a: Je breekt het TOCH niet. ('You won't break it ANYhow')

Stimulus 5b: Je BREEKT het toch niet. ('You won't BREAK it, will you?') 